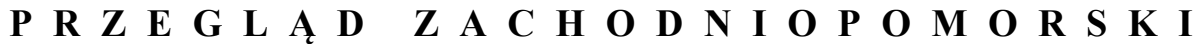 ROCZNIK XXXIII (LXII) ROK 2018 ZESZYT 1
}

\section{ADAM WĄTOR \\ Wydzial Humanistyczny, Uniwersytet Szczecinski \\ e-mail: adamw@univ.szczecin.pl \\ STRATEGICZNA ROLA TWIERDZY SZCZECIŃSKIEJ PODCZAS WOJNY W LATACH 1806-1807}

Słowa kluczowe: dzieje Szczecina, historia wojskowości, wojny napoleońskie

Keywords: the history of Szczecin, the history of Military Science, Napoleonic Wars

W napoleońskim systemie prowadzenia wojny twierdze odgrywały ważną rolę jako „oparcie dla manewru”, zabezpieczenie linii komunikacyjnych armii, stawały się „ośrodkami operacji”, miejscem gromadzenia rezerw i zaopatrzenia wojsk (magazyny i sprzęt) ${ }^{1}$. W artykule przedstawiono rolę twierdzy szczecińskiej w koncepcjach Napoleona i ich realizacji w okresie od końca października 1806 roku do sierpnia 1807 roku, zamykającego bezpośrednie działania wojenne wokół Szczecina. Fakt, że na interesującym nas obszarze nie doszło do spektakularnych walk i oblężeń, jak w przypadku Gdańska, Kołobrzegu, Grudziądza oraz twierdz śląskich, wpłynął na mniejsze zainteresowanie badaczy działaniami wojennymi na Pomorzu Zachodnim². Tymczasem liczba rozkazów i dyspozycji zawarta w Korespondencji Napoleona ${ }^{3}$ z tego okresu świadczy o wadze przypisywanej twierdzy Szczecin. W literaturze przedmiotu sygnalizowaną problematykę

1 M. Kukiel, Wojny napoleońskie, Warszawa 1927, s. 7, 298.

2 W niniejszym opracowaniu przyjęto współczesne nazewnictwo: Pomorze Zachodnie, mając świadomość braku precyzji posługiwania się tym terminem dla omawianych czasów.

3 Correspondance de Napoleon I-er. Publiee par ordre de l'Empereur Napoleon III, t. XIII, XIV, XV, Paris 1863-1864. 
opracowano w syntetycznych publikacjach poświęconych wojnie francusko-prusko-rosyjskiej w latach 1806-1807. Na plan pierwszy wysuwają się klasyczne opracowanie niemieckie na czele z E. Höpfnerem ${ }^{4}$ i O. Lettow-Vorbeckiem ${ }^{5}$. Przydatna jest również lokalna literatura pruska ${ }^{6}$. Spośród publikacji francuskich podstawę stanowi zbiór dokumentów dla wojny 1806-1807 opublikowany przez P.J. Foucarta ${ }^{7}$. Zachowały swą wartość opracowania A. Thiersa ${ }^{8}$ i zwłaszcza G. Lechartiera9 ${ }^{9}$ najbliższe niniejszemu tematowi. Należy uwzględnić również biografie francuskich dowódców prowadzących działania na interesującym nas obszarze (Joachima Murata, Jeana Lannesa, Antoine Lassalle'a). Informacje o zajęciu Szczecina przez Francuzów znajdują się we wszystkich opracowaniach dotyczących tej wojny ${ }^{10}$.

Na tym tle polska literatura naukowa poświęcona działaniom wojennym na Pomorzu Zachodnim w latach 1806-1807 prezentuje się skromnie. Powstałe jeszcze przed drugą wojną światową prace J. Staszewskiego, dotyczą przede wszystkim wojsk polskich na Pomorzu Gdańskim i Środkowym, tylko incydentalnie odnosząc się do roli Szczecina ${ }^{11}$. Podobną uwagę należy poczynić w odniesieniu do literatury powojennej ${ }^{12}$. Stosunkowo najlepiej rozpoznane są, dzięki badaniom H. Kroczyńskiego, działania wojenne wokół i podczas oblężenia Kołobrzegu oraz udział w nich wojsk polskich ${ }^{13}$. Na uwagę zasługują syntetyczne opracowania działań wojennych na Pomorzu Zachodnim w czasie wojen napoleońskich

4 E. von Höpfner, Der Krieg von 1806 und 1807. Ein Beitrag zur Geschichte der Preussischen Armee nach den Quellen des Kriegs-Archivs bearbeitet, Berlin 1852; korzystam z wyd. polskiego: Wojna z lat 1806-1807, t. I-IV, Oświęcim 2014-2016.

5 O. von Lettow-Vorbeck, Der Krieg von 1806 und 1807, t. II, IV, Berlin 1892, 1896.

6 Np. M. Wehrmann, Geschichte der Stadt Stettin, Stettin 1911 (rozdz. Stettins Franzosenzeit, s. $408-435)$.

7 P.J. Foucart, Campagne de Prusse (1806) a'pres les archives de la guerre, Paris 1890; Campagne de Pologne novembre-decembre 1806-janvier 1807(Pultusk et Golymin) a'apres les archives de la guerre, t. I-II, Paris 1882.

8 A. Thiers, Historya Konsulatu i Cesarstwa, t. III, Warszawa 1847; t. IV, Warszawa 1850.

9 G. Lechartier, Les Services de l'arriere a la Grande Armee en 1806-1807, Paris 1910.

${ }^{10}$ Np. F.L. Petre, Napoleon's Conquest of Prussia, London 1914, s. 252.

11 J. Staszewski, Wojsko polskie na Pomorzu w roku 1807, wyd. II, Oświęcim 2013.

${ }^{12}$ G. Zych, Rok 1807, Warszawa 1957; W.S. Mikuła, Działania zbrojne na Pomorzu w okresie wojen napoleońskich, w: Działania militarne na Pomorzu, red. W. Wróblewski, Warszawa 2001, s. $145-165$.

${ }^{13}$ H. Kroczyński, Wojsko polskie na Pomorzu Zachodnim i Krajnie w 1807, Warszawa 1990; tenże, Twierdza Kołobrzeg, Warszawa 1998. 
autorstwa B. Frankiewicza ${ }^{14}$, a także Z. Szultki ${ }^{15}$. Militarne aspekty nie znalazły szerszego odzwierciedlenia we współczesnej syntezie dziejów Szczecina ${ }^{16}$. Zasygnalizować należy również popularną literaturę przedmiotu ${ }^{17}$.

Zajęcie twierdzy Szczecin przez francuską kawalerię 30 października 1806 roku było faktem bez precedensu, nie napotkano bowiem na opór ze strony załogi pruskiej. Kluczowe staje się więc pytanie o możliwości prowadzenia skutecznej obrony twierdzy. Nie ulega wątpliwości, że jej stan nie był oceniany przez współczesnych za dobry. Fortyfikacje Szczecina przebudowywane w latach 1724-1740 z myślą o umocnieniu pruskiego panowania na obszarach przejętych od Szwedów, niekonserwowane i nieunowocześniane zgodnie z wymogami sztuki wojennej, w początkach XIX stulecia nie spełniały wymaganych standardów. Oprócz wału głównego składały się one z wysuniętych fortów - od strony południowozachodniej fortu „Prusy” (Preussen), od zachodniej - Wilhelma i od północy - Leopolda. Położona $\mathrm{z}$ dala od przewidywanego teatru działań, szczecińska twierdza nie została uwzględniona w pruskich planach wojennych $1806 \mathrm{roku}^{18}$. Wraz z przygotowaniami do wojny z Francją wymaszerowały z rejonu Szczecina przeznaczone do operacji na Pomorzu Szwedzkim wojska korpusu gen. Friedricha Adolfa von Kalckreutha, udając się do armii polowej. Niekorzystny rozwój wydarzeń wojennych na terenie Saksonii, klęski pod Jeną i Auerstädt (14.10.), odwrót pokonanej armii pruskiej na północny-wschód, spowodowały i tak już mocno spóźnioną decyzję Najwyższego Kolegium Wojskowego (17.10.) w sprawie przygotowania

${ }^{14}$ B. Frankiewicz, Wojny napoleońskie na terenie Pomorza Zachodniego, w: Z dziejów wojennych Pomorza Zachodniego. Cedynia 972 - Siekierki 1945, red. B. Miśkiewicz, Poznań 1972; tenże, Garnizony wojsk francusko-polskich na Pomorzu Szczecińskim i Gdańskim w latach 18071813, „Przegląd Zachodniopomorski” 1969, nr 2.

15 Z. Szultka, Pomorze Zachodnie w czasie wojen napoleońskich, w: Historia Pomorza, t. II, cz. III, red. G. Labuda, Poznań 2003, s. 763-772.

${ }^{16}$ Dzieje Szczecina 1806-1945, t. III, red. B. Wachowiak, Szczecin 1994.

${ }^{17}$ C. Domalski, Napoleoński Szczecin 1806-1813, Szczecin 2009. Barwny opis rokowań i zajęcia twierdzy zob. M. Dupont, Generat Lassalle, tłum. B. Wieniawa-Długoszowski, Kraków 1983, s. $119-130$.

${ }^{18}$ Skład garnizonu Szczecina (2 bataliony piechoty, 2 kompanie inwalidów, kompania artylerii) zob. H. Kemm, Die Garnisonorte der preussische Armee in Pommern von 1740-1806, Berlin 1937 (1983). 
szczecińskiej twierdzy do obrony. Zadanie powyższe powierzono dyrektorowi Departamentu Inżynierii gen. Levinowi von Geusau i oficerom inżynierii, wysłanym w tym celu do Szczecina ${ }^{19}$. Sprawa nabrała aktualności, gdy zawiodły nadzieje związane z pobytem i zapewnieniem bezpieczeństwa armii w przepełnionym wojskiem Magdeburgu. Decyzje podjęte 20 października 1806 roku przez głównodowodzącego Friedricha Louisa ks. Hohenlohe-Ingelfingen wyznaczały armii marsz w kierunku Szczecina, gdzie spodziewano się za zasłoną murów znaleźć czas na odpoczynek i reorganizację oddziałów.

W samej twierdzy za przygotowanie fortyfikacji odpowiedzialny był dyrektor Królewskiej Akademii Inżynierii w Poczdamie gen. Johann Bonawentura von Rauch. Realizowane prace z udziałem ściągniętych do Szczecina cieśli i robotników poprawiły stan umocnień. Usunięto z przedpola krzaki i drzewa, wykonano niezbędne naprawy wału głównego i fortu „Prusy”, inne wysunięte bastiony ze względu na ich zły stan zostały opuszczone. Przeprowadzono również przegląd stanu artylerii twierdzy i uzupełniono zapasy amunicji ${ }^{20}$. Nie odczuwano żadnych braków w zaopatrzeniu, w magazynach zgromadzona została wystarczająca ilość mąki, zboża, mięsa i paszy ${ }^{21}$. Obecność statków handlowych w szczecińskim porcie pozwalała na uzupełnianie innych potrzeb. Do dyspozycji pozostawały również duże zasoby drewna i innych materiałów przydatnych podczas oblężenia. Wskazane materiałowe zasoby i liczny garnizon ${ }^{22}$ stwarzały warunki do obrony, przewidywanej na trzy tygodnie, przy zastosowaniu przez przeciwnika regularnego oblężenia. Do twierdzy dotarł transport karabinów z ewakuowanych magazynów w Berlinie, co pozwoliło na rozbudowę garnizonu o żołnierzy - rozbitków $\mathrm{z}$ armii, przechodzących przez miasto. Istniała również możliwość sformowania brakującej w twierdzy kawalerii, niezbędnej dla przeprowadzenia rozpoznania. Zabrakło jedynie determinacji ze strony dowództwa twierdzy, złożonego z ludzi

19 Do Szczecina wyruszyły także wojska garnizonu berlińskiego (5 batalionów muszkieterskich, kompania artylerii oraz grupa kawalerii). Drogą wodną wysłano tam kasy i klejnoty koronne; E. Höpfner, Der Krieg..., t. II, s. 44.

${ }^{20}$ Tworzyło ją 187 armat oraz kolejne 94, które mogły być wykorzystane w razie konieczności. Przygotowano 11420 kul i granatów artyleryjskich oraz 1928 centnarów prochu; tamże, s. 136.

${ }^{21}$ Zgromadzono: 8 tys. wispli żyta, 700 wispli mąki, 4 tys. wispli owsa (wispel pruski $=1,348 \mathrm{~m}^{3}$ ); także stado 1,2 tys. wołów przepędzone tutaj z Kotliny Freienwaldzkiej; tamże, t. II, s. 136; O. Lettow-Vorbeck, Der Krieg..., t. II, s. 289. W rozważaniach o możliwości obrony należy wziąć pod uwagę rozkaz z 21.10.1608 r. wyekspediowania ze Szczecina do Gdańska wszystkich kas.

22 Tworzyły go trzecie bataliony muszkieterskie pułków piechoty: nr 1 Kunheim, nr 13 Arnim, nr 21 Braunschweig-Oels, nr 22 Pirch, nr 23 Winnig, nr 25 Möllendorf, nr 26 Larisch oraz kompania artylerii, razem 5184 żołnierzy i 100 oficerów. 
starych, zniedołężniałych, nienadających się do prowadzenia skutecznej obrony ${ }^{23}$. Kapitulacja głównej armii pruskiej pod Prenzlau (28.10.) i Pasewalk (29.10.) miała znaczenie decydujące, do Szczecina dotarły tylko drobne pododdziały oraz grupki zbiegłych z niewoli oficerów i żołnierzy, zamierzających kontynuować walkę. Dowództwo twierdzy odmówiło natomiast zgody na wpuszczenie kawalerii gen. Christopha Rudolfa von Bily, skazując ją w konsekwencji na kapitulację pod Anklam (1.11.).

Pojawienie się w południe 29 października 1806 roku od strony Löcknitz francuskiej brygady lekkiej kawalerii pod dowództwem gen. Antoine Charlesa Lassalle'a ${ }^{24}$, nie zaskoczyło strony pruskiej, ale w decydujący sposób wpłynęło na złamanie woli walki. W wyniku prowadzonych rozmów z Francuzami dowództwo twierdzy zdecydowało o podpisaniu kapitulacji ${ }^{25}$. Poranny meldunek marszałka Joachima Murata do cesarza zawierał lakoniczną informację: „Les hussards de $\mathrm{V}$ [otre] M[ajeste] prendront possession ce matin a 6 heures des portes de la place". Wiadomość, w którą nie od razu uwierzono we francuskiej kwaterze głównej, została tam przyjęta z nieukrywaną radością. W celach propagandowych podkreślano przejęcie artylerii, potężnych magazynów pruskich i zarekwirowanych w składach portowych towarów pochodzenia angielskiego, ale liczyły się przede wszystkim względy strategiczne - zdobycie, bez straty choćby jednego

${ }^{23}$ Dowództwo twierdzy: gubernator - gen. Friedrich Gisbert Wilhelm von Romberg (17291809), komendant twierdzy - Kurt Gottfried von Knobelsdorf (1735-1807), komendant fortu „Prusy” - gen. Johann Bonawentura von Rauch (1740-1814). Skorygować należy wprowadzoną przez E. Höpfnera a powtarzaną w literaturze przedmiotu (B. Frankiewicz, Z. Szultka) błędną informację o wieku v. Romberga.

${ }^{24}$ Brak szczegółowych danych na temat liczebności brygady. W chwili rozpoczęcia działań wojennych liczyła w 5 i 7 pułku huzarów 1181 żołnierzy i 1242 konie; pod Szczecin dotarło zapewne 600-700 (800) huzarów.

${ }^{25}$ Warunki kapitulacji (29.10.1806 r., godz. 11.30 w nocy): „Garnizon wyciągnie z honorami woyskowemi, złoży broń na stoku i jako będący w niewoli uda się do Francji. Officerowie wolni są na słowo honoru i udadzą się za paszportami gdzie się im podoba. - Officerowie zatrzymają szpady, konie i wszystko co do nich należy. - Wszelka własność Króla Pruskiego oddana będzie woyskom francuskim. - Zostawia się garnizonowi 24 godzin do pokończenia interesów; w tym czasie brama Berlińska i most na Odrze oddane będą straży francuskiey. - Własność mieszkańców ma być szanowana; familie osób woyskowych zostaną pod opieką woysk francuskich, chorych i rannych zostawia się wspaniałomyślności tychże woysk”. Cyt. za: „Gazeta Warszawska” nr 99, 12.12.1806; zob. Die Kapitulation der Stadt und Festung Stettin, w: Die Feldzüge von 1806 und 1807 in einer historisch, politisch, militärische Darstellung nebst den offiziellen Aktenstücken, Zweiter Teil, b.m.w., 1809, s. 79-81; F. Thiede, Chronik der Stadt Stettin, Stettin 1849, s. 861; H. Granier, Die Kapitulation von Stettin 1806 und der Staatsminister von Ingersleben, „Baltische Studien" 1900, nr 4, s. 7-14; M. Wehrmann, Geschichte..., s. 416-417; J. Tulard, Murat, Gdańsk 2002, s. 107. 
żołnierza, przeprawy przez Odrę ${ }^{26}$. Zgodnie z warunkami kapitulacji, Francuzi przejęli Bramę Berlińską oraz posterunki przy moście nad Odrą, podczas gdy kawaleria Lassalle’a ruszyła w kierunku położonego na prawym brzegu rzeki fortu Dąbie (Damm) ${ }^{27}$. W ślad za nią podążył prowadzony przez gen. Dominique Vedela oddział z 88 pułku piechoty liniowej, w godzinach przedpołudniowych 1 listopada 1806 roku zajmując bez walki fort ${ }^{28}$.

Czasowo komendę w Szczecinie sprawował szef sztabu V korpusu gen. Claude Victor-Perrin, a wieczorem 1 listopada swoją kwaterę główną założył marszałek Jean Lannes. Informując cesarza o trudnej sytuacji podległych mu oddziałów, wyczerpanych długimi marszami i walkami, wyrażał nadzieję na wykorzystanie miejscowych zapasów dla uzupełnienia zużytego obuwia i mundurów, także zaopatrzenia żołnierzy w płaszcze; zapowiedział sporządzenie szczegółowego inwentarza zasobów materiałowych znajdujących się w Szczecinie. Pisał: „Zgromadzę wszystkie, ile będę mógł, zboże i mąkę na pomnożenie naszych zapasów; każę pobudować piece i wypiekać sucharów ile tylko będzie można". Kolejny raport marszałka z 2 listopada, zawierający bardziej szczegółowe informacje o stanie twierdzy, sporządzony został już po lustracji przeprowadzonej wspólnie z przybyłym tutaj z kwatery głównej gen. Francois Charles de Chasseloup-Laubat, szefem wojsk inżynieryjnych Wielkiej Armii. Lannes relacjonował: „uważa ją [twierdzę - dop. A.W.] za złą, ja także mniemam, że wiele trzeba będzie wyłożyć pieniędzy, żeby ją przyprowadzić do stanu obrony”. Inspekcją objęto również, opisany jako „prześliczna pozycja naturalna”, fort Dąbie. „Mniemam, że

${ }^{26}$ Wielki ks. Bergu do cesarza, Löcknitz 30.10.1806, P.J. Foucart, Campagne de Prusse..., t. II, s. 525; Napoleon do W. ks. Bergu, Berlin 31.10.1806, Correspondance..., t. XIII, nr 11121, s. 443; A. Thiers, Historya ..., t. III, s. 587. W doniesieniach francuskich (24 Bulletin de la Grande Armee, Berlin 31.10.1806, Correspondance..., t. XIII, nr 11135, s. 450), także w literaturze naukowej (G. Lechartier, Manewr na Pułtusk, Oświęcim 2011, s. 38; Z. Szultka, Pomorze Zachodnie..., s. 765) powtarzano zawyżoną liczbę kapitulujących Prusaków: 6 tys. żołnierzy wraz z 160 działami. Por. Victoires, conquetes et desastres, Revers et Guerres Civiles des Francais de 1792 a 1815, t. 7, Paris 1819, s. 368. O zajęciu „Szczecina” zob. „Gazeta Poznańska” nr 105, 10.12.1806.

27 „Jeńcy w Szczecinie chcieli się zbuntować, grozili swoim oficerom i bili ich. To był najwyższy czas, aby przybyła piechota gen. Victora. Jak tylko się pozbyłem tego obciążającego zadania, ruszyłem dalej ze swoją brygadą do Damm". Gen. Lassalle do W. ks. Bergu, Falkenwalde [Tanowo], 30.10.1806, P.J. Foucart: La cavalerie pendant la campagne de Prusse (7 octobre-7 novembre 1806), Paris 1880, s. 215.

28 Garnizon Dąbia stanowił III muszkieterski batalion pułku Pircha, komendant fortu kpt. Karl Heinrich Wittke. E. Fritz, Aus schwerer Zeit. Erinnerungen an die Drangsale und Leiden der Stadt und Festung Altdamm aus der Zeit der Franzosenherrschaft in den Jahren 1806-1813, Altdamm 1902, s. 8. 
jeżeli Wasza Cesarska Mość zechce iść naprzód, uczyni tę pozycję niezdobytą" konkludował Lannes. Marszałek zwrócił się również z prośbą o zgodę na skierowanie dywizji gen. Louisa Gabriela Sucheta i brygady lekkiej kawalerii gen. Anne Treilharda do Stargardu. Uzasadnienie brzmiało praktycznie: „Tym sposobem oszczędzilibyśmy żywności twierdzy Szczecina, której wszakże jeszcze się nie dotknąłem. Żołnierze rozłożeni są w okolicach i żywią się u mieszkańców”29. Postępowanie marszałka odpowiadało intencjom Napoleona. W dyspozycji dla Lannesa z 3 listopada 1806 roku cesarz zwrócił uwagę na zgromadzone zapasy mąki. „Są nam bardzo potrzebne, gdyż ta twierdza stanie się naszym centrum operacyjnym [podkr. - A.W.]”. Obawiał się też rewolty ze strony pruskiej, nalegając:

Rozumiem, że nie zapomniał Pan rozkazać rozbrojenia wszystkich mieszkańców. Należy rozkazać, aby zostało ono zrealizowane w ciągu dwudziestu czterech godzin oraz aby zabezpieczono broń w cytadeli. Proszę również zająć się poszukiwaniem magazynów. Powinno być ich sporo w Szczecinie. Od teraz komunikacja będzie musiała odbywać się drogą przebiegającą po prawobrzeżu. Zajmujemy już obydwa brzegi Odry ${ }^{30}$.

Według wstępnych szacunków, w magazynach Szczecina znaleziono ilość zboża wystarczającą do wypieku 3-4 mln racji chleba oraz piece, w których dziennie można było wypiec 50 tys. racji. Dodatkowo w zajętym 5 listopada 1806 roku Stargardzie znajdowało się 12 tys. porcji chleba przygotowanego dla armii pruskiej $^{31}$.

Cenną zdobyczą okazały się znalezione w Szczecinie wielkie zapasy wina, wódki i rumu, od 21 listopada 1806 roku przewożonego do Kostrzyna i stąd

${ }^{29}$ Lannes do Napoleona, Pasewalk 1.11.1806 i Stettin 2.11.1806, P.J. Foucart, Campagne de Prusse..., t. II, s. 597-598, 645-647. Lannes wyliczał zdobycze: 150 ton prochu, 46357 kwintali żyta, 19785 kwintali owsa, 6182 kwintali mąki. Por. A. Thiers, Historya ..., t. III, s. 586; Ch.A. Thoumas, Le marechall Lannes, Paris 1891, s. 173-177. Gen. A. Belliard, sygnatariusz aktu kapitulacji, pisał do Berthiera 30.11.1806: „Stettin est une grande ville ou nous trouverons beauccoup de ressources”. P.J. Foucart, Campagne de Prusse..., t. II, s. 528.

${ }^{30}$ Napoleon do Lannesa w Szczecinie, Berlin 3.11.1806, Correspondance..., t. XIII, nr 11160, s. 467. Odpowiadając Lannesowi cesarz pisał: „Zobaczy Pan na liście spraw, że przeznaczyłem Panu 6000 płaszczy żołnierskich do zabrania ze Szczecina. Jeśli Pan będzie potrzebował ich 15000 , to niech Pan o tyle poprosi, bowiem zabierze się wtedy mniej sztuk z zaplecza armii"; tamże. Braki obuwia nakazywał rozwiązać poprzez uruchomienie „ich produkcji” w Szczecinie, powołując się na Berlin, gdzie wyrabiano 500 par dziennie.

${ }^{31}$ Lannes do Napoleona, Szczecin 5.11.1805, Correspondance..., t. XIII, nr 11182, s. 484. 
transportowanego do Wielkiej Armii ${ }^{32}$. Napoleon również rozkazał generalnemu intendentowi Wielkiej Armii Pierre Daru ustalenie wysokości kontrybucji możliwej do ściągnięcia od mieszkańców Szczecina. „Chciałbym, żeby została ona szybko nałożona na to miasto celem wypłacenia za jeden miesiąc żołdu korpusowi marszałka Lannesa, który przejmie twierdzę" ${ }^{\text {"33 }}$. Zarządzono na szeroką skalę rekwizycje rzeczy potrzebnych dla armii ${ }^{34}$.

W miarę rozwoju sytuacji militarnej, wraz ze sforsowaniem linii Odry i możliwością kontynuowania działań ofensywnych na wschód - przeciwko nadciągającym wojskom rosyjskim, Napoleon konkretyzował zadania związane z posiadaniem szczecińskiej twierdzy. Uwzględniał takie kwestie, jak zabezpieczenie i skrócenie linii komunikacyjnych Wielkiej Armii, a także stworzenie bazy zaopatrzeniowej. W dyspozycji dla marszałka Lannesa z 5 listopada 1806 roku znalazły się znamienne słowa: „Moją intencją jest ufortyfikowanie Szczecina”. Nakazywał podjęcie niezbędnych prac, mających na celu podniesienie obronności twierdzy, wyznaczenie stałych załóg dla poszczególnych fortów, ich aprowizację i przeznaczenie na garnizon Szczecina 2-3 tys. żołnierzy. Szczegółowe zarządzenia zawierał rozkaz dla gen. F. Chasseloupa, któremu zlecono kierownictwo prac nad modernizacją fortów (naprawa palisad i stanowisk artyleryjskich, przygotowanie zapasów faszyny).

Natomiast mury obronne trzeba będzie tak przygotować, żeby wróg nawet kontrolując wysunięte forty nie mógł podjąć żadnych kroków przeciwko fortyfikacjom zewnętrznym. Nie można mu pozwolić na to, aby się schował między dwoma fortami. Należy zadbać o to, aby nie był w stanie tej samej nocy wspiąć się na fortyfikacje zewnętrzne oraz na mury obronne.

Zwracał uwagę na korzystne, sprzyjające obronie warunki terenowe (bagnisty teren). Do obsady fortu „Prusy” przeznaczał 400 żołnierzy, fortu Wilhelma - 200, fortu Leopolda - 100; kolejnych 400-500 miało stanowić załogę Dąbia. Wszystkie wymienione forty były zdolne do prowadzenia samodzielnej obrony. Kolejnych 600 żołnierzy stacjonować powinno w samym mieście, z zadaniem

${ }^{32}$ Według raportu z 6.12.1806 w Szczecinie znaleziono: 7436400 racji wina, 1069440 racji wódki i 238880 racji rumu; G. Lechartier: Les Services..., s. 656.

${ }^{33}$ Napoleon do Daru, Berlin 3.11.1806, Correspondance..., nr 11161, s. 468; G. Lechartier: Les Services..., s. 436.

${ }^{34}$ Rozkaz Napoleona z 14.11.1806 nakazywał ,wydusić” ze Szczecina, Frankfurtu i Kostrzyna 50 tys. par butów; Correspondance..., nr 11256, s. 535. 
obsady wału głównego twierdzy, zapewnienia wymaganej rezerwy i wystawienia posterunków ${ }^{35}$. Rozkaz cesarski wymagał wydzielenia 200 żołnierzy do działań obserwacyjnych. Do Szczecina wysłana została także kompania 5 pułku francuskiej artylerii pieszej (100 żołnierzy i 9 robotników służby artylerii). Właściwe rozmieszczenie wojsk miało maskować ich słabość, ale także umożliwiało racjonalne gospodarowanie siłami żołnierzy, z zapewnieniem im niezbędnego odpoczynku po służbie wartowniczej. W dyspozycji z 7 listopada 1806 roku wraz z korektą liczebności załóg poszczególnych fortów, znalazła się następująca konstatacja:

Broniony przez 1200 żołnierzy oraz wyposażony w armaty na wszystkich bastionach Szczecin powinien być chroniony przed wszelkim zaskoczeniem, pod warunkiem, że tak jak to robią Turcy oraz według obyczaju, który równie skutecznie pielęgnowaliśmy, zamiast zaciągać wartę codziennie, jedna kompania ma strzec jedno działo i zamykać się w jednym bastionie. Wymaga się, aby zmiana nocna została do 10 rano. Kiedy ma się już pewność, że wróg się nie pojawi, zostawia się tylko połowę żołnierzy przy każdym dziale, a reszcie pozwala na obchód po mieście ${ }^{36}$.

Cesarskie dyspozycje mogą uchodzić za przykład znajomości sztuki fortyfikacyjnej i wzór instrukcji zabezpieczającej załogi przed nagłym atakiem ze strony przeciwnika.

W przygotowaniach obronnych ważna rola przypadła fortowi w Dąbiu, uważanemu przez Francuzów za przyczółek szczecińskiej twierdzy na prawym brzegu Odry. Wkrótce po jego obsadzeniu (1.11.1806) podjęto na szeroką skalę modernizację fortyfikacji, angażując do tych prac ściągniętych z okolicy robotników. Wzmocniono załogę, przygotowując ją na niespodziewany atak ${ }^{37}$. Zapo-

\footnotetext{
${ }^{35}$ Napoleon do gen. Chasseloup, 5.11.1806 i Lannesa, Berlin 5.11.1806, tamże, t. XIII, nr 11178, s. 482-483, nr 11182, s. 485; P.J. Foucart, Campagne de Prusse..., t. II, s. 723; G. Lechartier, Manewr..., s. 86 .

${ }^{36}$ W porównaniu z rozkazem z 5.11.1806 przewidziano dla fortów: „Prusy” - 200, Wilhelma i Leopolda - po 100, Dąbia - 200 ludzi. Napoleon do Lannesa, Berlin 7.11.1806, Correspondan$c e . .$, t. XIII, nr 11200, s. 496-497. Prace fortyfikacyjne wzbudziły uznanie Prusaków. Zob. Von J.C. Gass., Stettin 14.12.1806, w: F. Schleiermacher, Briefwechsel und biographische Dokumente, B. 9, Briefwechsel 1806-1807, Berlin 2011, s. 251.

${ }^{37}$ Pracami fortyfikacyjnymi w Dąbiu kierował kpt. artylerii badeńskiej Müller. Od 13.11 .1806 załogę fortu tworzyło 6 kompanii badeńskiej piechoty (400) pod dowództwem ppłk. Karla von Stockhorna oraz 40 francuskich kanonierów. Od 18.11. komendantem był Louis Chapui, dowódcą saperów - kpt. Virvaux, artylerii - por. Doyen. Po wymarszu Badeńczyków 31.01.1807 ich miejsce zajął batalion francuski. E. Fritz, Aus schwerer Zeit..., s. 12-13, 17; G. Lechartier: Les Services..., s. 437. Przytoczone przez Z. Szultkę dane (Pomorze Zachodnie..., s. 766) są nieporozumieniem.
} 
biegliwość okazała się uzasadniona biorąc pod uwagę aktywność oddziałów pruskich, docierających do przedpola Dąbia w styczniu-lutym 1807 roku.

Siły przeznaczone na stały garnizon twierdzy były słabe, mimo to Napoleon uznał je za wystarczające pod warunkiem utrzymywania stałej gotowości bojowej. Liczebną słabość złagodzić miał zastosowany przez Napoleona system rotacji wojsk. Warto nieco bliżej prześledzić ten modelowy proces. Wielkie zgrupowania francuskie i sojusznicze przechodzące przez Szczecin w marszu nad dolną Wisłę uzupełniały załogę twierdzy i wspierały ją w realizacji postawionych zadań. Po wymarszu wojsk V korpusu w kierunku Piły i Torunia ${ }^{38}$, na rozkaz cesarza pozostawiono w Szczecinie 1200 żołnierzy 28 pułku lekkiego, przybyłego z Moguncji i świeżo włączonego do V korpusu ${ }^{39}$. Z kolei 12 listopada 1806 roku dotarła tutaj, stacjonująca wcześniej w Kostrzynie, badeńska brygada piechoty pod dowództwem gen. Josefa von Clossmana (2263 żołnierzy) ${ }^{40}$. Żołnierze badeńscy stanowili przez najbliższe tygodnie główną siłę bojową garnizonu, a 900 z nich detaszowano do obsady fortów; od 23 stycznia 1807 roku zostali włączeni do dywizji gen. Jeana Francois Menarda, należącej do formowanego X korpusu Wielkiej Armii z zadaniem podjęcia oblężenia Gdańska. Czasowo szczeciński garnizon został wzmocniony przez niewielki kontyngent wirtemberski (600 żołnierzy $)^{41}$. Kolejno dotarły oddziały I, V, III i VII korpusów oraz zbiorczy oddział dragonów z Poczdamu (przybyły 7.12.1806). Pobyt wykorzystano na dokończenie szkolenia, wymienione oddziały pełniły rolę wojsk etapowych. W styczniu 1807 roku, w związku z koncentracją wojsk X korpusu, garnizon Szczecina osiągnął swój najwyższy stan liczebny. Do przebywających tu żołnierzy dołączyły, idące z Berlina, dwa bataliony piechoty wielkiego księstwa würzburskiego (1400 żołnierzy $)^{42}$. Odnotować należy również przemarsz przez Szczecin Legii Północnej,

${ }^{38}$ V korpus liczył jedynie 479 oficerów i 14644 żołnierzy, bowiem 21 pułk lekki (1414) oraz część 103 pułku (200) przeznaczono do konwojowania jeńców pruskich do Spandau. Lannes do cesarza, Szczecin 4.11.1806, P.J. Foucart, Campagne de Pologne..., t. I, s. 46.

${ }^{39}$ Cesarz do Lannesa, Berlin 7.11.1806, tamże, s. 69. W raporcie z 11.11.1806 Lannes pisał: „Zostawiłem w Szczecinie 28 pułk piechoty lekkiej. Nigdy nie widziałem pułku słabiej wyposażonego niż ten", tamże, s. 89.

${ }^{40}$ Do tego dochodziła kawaleria (564), kompania wybiorcza (140), artyleria (219) oraz służba pociągów (336 ludzi); G. Lechartier, Les Services..., s. 438-439.

${ }^{41}$ Napoleon do Lannesa, Berlin 7.11.1806, Correspondance..., t. XIII, nr 11200, s. 497.

${ }^{42}$ Pod dowództwem płk. Gebsattela wymaszerowały ze Szczecina 15.05. i zostały włączone do VIII korpusu, następnie uczestniczyły w oblężeniu Grudziądza. 
dowodzonej przez gen. Józefa Zajączka ${ }^{43}$. Dla polskich żołnierzy pobyt w mieście wiązał się nie tylko z odpoczynkiem po wyczerpującym marszu z Lipska przez Magdeburg, ale także z możliwością uzupełnienia umundurowania, oporządzenia i uzbrojenia. Następnie Legia Północna wzięła udział w zdobyciu Tczewa i oblężeniu Gdańska.

Miejsce wymienionych wojsk zajęły oddziały włoskie (1 pułk piechoty lekkiej, 1 pułk piechoty liniowej) i francuskie (fizylierzy gwardii), podążające do Wielkiej Armii. W marcu znalazły się tutaj: słaby liczebnie kontyngent sasko-weimarski ${ }^{44}$, zakłady I, VIII i X korpusów, dwa bataliony gwardii paryskiej oraz 7 pułk prowizoryczny, złożony z żołnierzy kierowanych dla uzupełnienia stanów etatowych jednostek Wielkiej Armii ${ }^{45}$. Po ich odmarszu w Szczecinie pozostały jedynie formacje zakładowe, wydzielone grupy z pułków prowizorycznych oraz czasowo niezdolni do służby, inwalidzi, ranni i chorzy ${ }^{46}$. Dopiero w początkach czerwca dotarł specjalnie sformowany dla obsady szczecińskiej twierdzy batalion garnizonowy ${ }^{47}$.

W tym samym czasie ukształtowały się francuskie władze wojskowe i cywilne. Na polecenie cesarza intendent generalny Pierre Daru zorganizował wojenną administrację francuską na okupowanych terenach pruskich. Jej głównym zadaniem było ściągnięcie nakazanej przez Napoleona kontrybucji, niezbędnej dla utrzymania francuskich garnizonów ${ }^{48}$. Szczecin stał się centrum wojskowych

${ }^{43}$ Utworzona na podstawie dekretu Napoleona z St. Cloud z 22.09.1806 i rekrutowana z b. wojskowych pruskich pochodzenia polskiego; w korpusie oficerskim dominowali Francuzi. Według stanu z 16.01.1807 liczyła 4966 żołnierzy; zob. Correspondance..., t. XIII, nr 11494, s. 103; M. Chojnacki, Z dziejów polskiej Legii Pótnocnej 1806-1808, „Wojskowy Przegląd Historyczny” 1960, nr 1, s. 137.

${ }^{44}$ L.v. Seebach, Geschichte des Feldzüges des herzoglich Sachsen-Weimarischen Scharffschützenbattalions im Jahr 1806 und des Infanterieregiments der Herzoge von Sachsen in den J. 1807, 1808, 1810 und 1811, Weimar 1838, s. 65-66; Napoleon do gen. Clarke, Osterode 1.04.1807, Correspondance..., t. XV, nr 12260, s. 6.

${ }^{45}$ G. Lechartier, Les Services..., s. 439; Napoleon do [Jeana Jacques] Cambaceresa, Warszawa 27.01.1807, Correspondance..., t. XIV, nr 11695, s. 235; Napoleon do gen. Clarke, Osterode 1.04.1807, tamże, t. XV, nr 12260, s. 6.

4621 grudnia obsada szczecińskiego szpitala wojskowego: pierwszy chirurg adiutant-mjr Petitfils starszy, chirurdzy: Petitfils mł., Viallard i Ravet; G. Lechartier, Les Services..., s. 621.

${ }^{47} \mathrm{Na}$ rozkaz Napoleona z 15.04.1806 formowano bataliony garnizonowe do obsady twierdz, Correspondance..., t. XV, nr 12383, s. 75-76. Batalion w Szczecinie na d. 9.06.1806 liczył 579, a 23.06. - 1355 ludzi pod dowództwem kpt. Viriota; G. Lechartier, Les Services..., s. 439.

48 Napoleon do generalnego intendenta, Berlin 2.11.1806, Napoleon do gen. [Jeana Leonarda] Lemarois, Berlin 19.11.1806, Correspondance..., t. XIII, nr 11142, s. 454, nr 11280, s. 552. 
władz francuskich na Pomorzu. Funkcję tymczasowego komendanta sprawował od 3.11.1608 gen. Georges Frederic Denzel, zastąpiony 13.11. przez mianowanego na stanowisko gubernatora prowincji Pomorze gen. Pierre Thouvenota, a który według słów Napoleona „dobrze rozumiał specyfikę fortyfikacji”, pełniąc wcześniej podobne funkcje w Würzburgu i Erfurcie ${ }^{49}$. Od 15 kwietniu 1807 roku został zastąpiony przez gen. Jeana Jacquesa Lieberta, dotychczasowego gubernatora w Poznaniu. W odróżnieniu od swego poprzednika, Liebert postępował rygorystycznie w stosunku do pruskich władz administracyjnych i skutecznie egzekwował potrzeby francuskiego garnizonu. Funkcję cesarskiego komisarza i intendenta finansowego pełnił l'Aigle ${ }^{50}$. Jego zadania przejęli następnie konsulowie Francois Billiot ${ }^{51}$ i Amadee Chaumette des Fosses. Ich zadania sprowadzały się do zabezpieczenia materialnych potrzeb wojsk francuskich, egzekwowania kontrybucji, czuwania nad przestrzeganiem blokady kontynentalnej i troski o szeroko rozumiane interesy cesarstwa. $Z$ polecenia władz francuskich w wielkich miastach zorganizowano milicje municypalne, dla Szczecina miała ona liczyć 40 osób $^{52}$. Utworzono również sześcioosobową komisję kwaterunkową, zadaniem której stało się przygotowanie kwater dla napływających do miasta żołnierzy francuskich ${ }^{53}$. Wykorzystując zgromadzone w mieście zapasy, na polecenie cesarza przygotowano tysiące racji chleba i sucharów, a także mięsa dla Wielkiej Armii, pomimo przeszkód związanych z brakiem odpowiedniej ilości

Wyznaczona na $10 \mathrm{mln}$ franków (2,5 mln talarów), obniżona na prośbę mieszkańców, kontrybucja spłacona została dopiero w 1808 r., częściowo w naturaliach; F. Thiede, Chronik..., s. 862; B. Frankiewicz, Wojny..., s. 232; Z. Szultka, Pomorze Zachodnie..., s. 769.

49 Szef sztabu [L.A. Berthier] do gen. brygady Thouvenot, komendanta Erfurtu, Berlin 2.11.1806, P.J. Foucart, Campagne de Prusse..., t. II, s. 660; Napoleon do Lannesa, Berlin 5.11.1806, Correspondance..., t. XIII, nr 11182, s. 485. Sztab twierdzy na d. 23.11.1806: gubernator - Thouvenot, gubernator wojskowy miasta - płk Vincenti, adiutant placu - kpt. Petitgrand, jego adiutant - por. badeński Hensch, szef artylerii - Devaux, szef batalionu saperów - Baranon, komisarz wojskowy - Vast, lekarz - Axel, główny chirurg - Dancel, główny farmaceuta - Bardot, poborca podatkowy - Bayard. Komendanci: fortu Dąbie - Chapui, fortu „Prusy” - kpt. Minet, G. Lechartier, Les Services..., s. 437.

${ }^{50} \operatorname{Dr}$ [Karl] Blasendorf, Aus der Franzosenzeit, „Baltische Studien” 1879, nr 29, s. 65.

${ }^{51}$ Francois Billiot (1748-1841) od 03.1800 r. konsul handlowy przy francuskiej agendzie konsularnej w Szczecinie; zob. Handbuch über den Koeniglich-Preussischen Hof und Staat für das Jahr 1804, b.m.w., s. 461.

${ }^{52}$ Note pour L'intendent general, Berlin 2.11.1806, P.J. Foucart, Campagne de Prusse, t. II, s. $652-653$.

${ }^{53}$ M. Stelmach, Pruskie władze administracyjne miasta Szczecina w okresie okupacji francuskiej (1807-1813), „Przegląd Zachodniopomorski” 1980, z. 1, s. 59. 
środków transportowych ${ }^{54}$. W styczniu 1807 roku na polecenie cesarza wizytację w Szczecinie przeprowadził oficer ordynansowy Henri Amadee Mercure de Turenne, który miał zapoznać się ze stanem fortyfikacji, szpitala wojskowego i garnizonu ${ }^{55}$.

W działaniach oblężniczych prowadzonych pod Gdańskiem wykorzystano ciężkie działa wysłane ze Szczecina 27 kwietnia 1807 roku konwojem kierowanym przez płk. Jeana Pierre Dogureau ${ }^{56}$. Artylerii tej użyto następnie podczas oblężenia twierdzy kołobrzeskiej.

W strategicznych koncepcjach Napoleona szczecińskiej twierdzy wyznaczono zapewnienie łączności z francuskimi wojskami po obu stronach Odry. Odnosiło się to do sił głównych Wielkiej Armii nad dolną Wisłą i oddziałów znajdujących się na zachód od Odry, blokujących szwedzką twierdzę w Stralsundzie (VIII korpus pod dowództwem marszałka Eduarda Adolphe Mortiera). W dyspozycji przekazanej przez szefa sztabu WA marszałka Louisa Alexandra Berthiera 27 listopada 1807 roku gen. P. Thouvenotowi przewidywano niebezpieczeństwo pruskiej dywersji od strony Gdańska i Grudziądza, wobec której miał wystąpić garnizon Szczecina (3 tys. Badeńczyków i tys. Francuzów); nakazywano stałą obserwację dróg komunikacyjnych w kierunku Gdańska, Grudziądza i Poznania. W tym celu ustanowiono obok stałych załóg w większych miejscowościach, sieć posterunków obserwacyjnych oddalonych od siebie o 2-2,5 km. Gen. Thouvenot miał utrzymywać ciągłą gotowość bojową podległych mu oddziałów, rozmieścić $\mathrm{w}$ fortach artylerię, przygotować niezbędne zapasy amunicji i aprowizację. Nie licząc się ze słabością szczecińskiego garnizonu wyznaczono mu także zadanie wystawienia posterunków wzdłuż Odry, aż do kanału Oderberg, „w każdym zagajniku” i „przy każdym moście”57. Uszczelnienie kontroli linii Odry wynikało z częstego przekraczania rzeki przez byłych pruskich wojskowych, w części zbiegłych lub uwolnionych z niewoli, zmierzających do twierdz w Kołobrzegu,

\footnotetext{
${ }^{54}$ Napoleon nakazywał upieczenie 100 tys. porcji chleba komiśnego oraz, o ile można, 200 tys. porcji sucharów. Napoleon do Daru, Berlin 3.11.1806, Correspondance..., t. XIII, nr 11161, s. 468. Z liczącego 908 wołów stada wysłano ze Szczecina do Kostrzyna 441 sztuk, kolejne 200 przekazano $\mathrm{V}$ korpusowi.

${ }^{55}$ Napoleon do Turenne, 8.01.1807, tamże, t. XIV, nr 11590, s. 170

${ }^{56}$ Eskortę stanowił przechodzący przez Szczecin 19 pułk liniowy; G. Lechartier, Les Services..., s. 542.

57 Napoleon do gen. Clarke, Międzyrzec [Meseritz] 27.11.1806, Correspondance..., t. XIII, nr 11313, s. 575; G. Lechartier: Manewr..., s. 86.
} 
Gdańsku i Grudziądzu, bądź podejmujących działania w ramach tworzonych na Pomorzu formacji partyzanckich.

W drugim przewidywanym wariancie, gdyby zagrożenie dla linii komunikacyjnych Wielkiej Armii nadeszło od strony zachodniej, z Pomorza szwedzkiego, gen. Thouvenot miał nakazane współdziałanie z wojskami VIII korpusu, z przewidywanym rejonem koncentracji wokół Anklam (gdzie 12.12.1807 umieszczono kwaterę główną korpusu) i zadaniem obrony linii dolnej Odry ${ }^{58}$. W szerszym ujęciu strategicznym gwarantowano także utrzymanie łączności z francuskimi rezerwowymi formacjami, znajdującymi się nad Renem z ośrodkiem w Moguncji, skąd kierowano uzupełnienia dla armii. Dzięki twierdzom w Szczecinie, Kostrzynie (zajęty 1.11.1807 przez wojska III korpusu) i Głogowie (zdobyty 2.12.1807 przez IX korpus po oblężeniu), strategiczna linia Odry znajdowała się w rękach francuskich. W rezultacie skróceniu uległy linie komunikacyjne Wielkiej Armii, wymienione twierdze gwarantowały również względną stabilność logistyczną głównych sił, walczących na północnym Mazowszu i w Prusach Wschodnich ${ }^{59}$. Dzięki gromadzonym w twierdzy zapasom, przechodzące przez Szczecin oddziały francuskie i sojusznicze uzupełniały tu swój ekwipunek, amunicję i uzbrojenie. W przypadku niepowodzenia twierdze mogły zostać wykorzystane jako punkty oparcia dla wycofującej się armii.

Równie ważne okazały się zadania obliczone na pacyfikację obszaru Pomorza. Garnizon Szczecina wraz z wojskami przechodzącymi przez miasto odegrał istotną rolę w zwalczaniu pruskiego Freikorpsu, zorganizowanego przez por. Ferdinanda von Schilla i mającego oparcie w twierdzy kołobrzeskiej ${ }^{60}$. Jego aktywność, działania na francuskich liniach komunikacyjnych, przechwytywanie transportów żywności, paszy i innych materiałów (broni, amunicji, sprzętu) kierowanych do twierdzy szczecińskiej, zabieranie kas miejskich, atakowanie drobnych posterunków francuskich i sojuszniczych, wywoływały duże zaniepokojenie we francuskim dowództwie. Gubernator P. Thouvent oświadczył nawet, że dopóki garnizon

\footnotetext{
${ }^{58}$ Napoleon do marszałka Mortiera, 5.11., 7.11., 16.11., 21.11.1806, Correspondance..., t. XIII, nr $11175,11198,11268,11285$, s. $480,484,543,558$.

${ }^{59}$ A. Thiers (Historya ..., t. IV, s. 115) zwrócił uwagę na transporty wina i wódki kierowane z Berlina i Szczecina do magazynów w Toruniu; zob. Note, Berlin 8.11.1806, P.J. Foucart: Campagne de Prusse..., t. II, s. 781.

${ }^{60}$ Obszernie o działaniach Schilla: E. Höpfner, Der Krieg..., t. IV, s. 311-345; O. Zimmermann, Ferdinand von Schill. Ein Heldenleben, Berlin 1948, s. 71-99; M. Rink, Patriot und Partisan, w: Für die Freiheit, gegen Napoleon. Ferdinand von Schill, Preussen und die Deutsche Nation, Köln, Weimar, Wien, Böhlau 2009, s. 77-78.
} 
Kołobrzegu nie zostanie skutecznie zablokowany przez oddziały liniowe, zmuszony będzie do całkowitego „porzucenia prawego brzegu Odry”, dysponuje bowiem w Szczecinie jedynie nieostrzelanymi rekrutami, nienadającymi się do obrony całej prowincji ${ }^{61}$. Działaniom pruskim sprzyjał zalesiony obszar, także wsparcie miejscowej ludności, zniechęconej rekwizycjami prowadzonymi przez Francuzów, obciążonej kosztami utrzymania stacjonujących w miastach i miasteczkach oddziałów. Prusacy podjęli w tym czasie działania na szerszą skalę, atakując ważne punkty strategiczne na Pomorzu Zachodnim. Jedną z większych akcji bojowych była próba opanowania wyspy Wolin i dalej - Uznam ${ }^{62}$, z wyraźnym zamiarem nawiązania bliższego współdziałania z wojskami szwedzkimi w rejonie Stralsundu. Akcja nie zakończyła się powodzeniem, ponieważ przewidując możliwość silniejszego pruskiego ataku w tym rejonie, francuskie dowództwo podjęło niezbędne kroki. Już w połowie listopada gen. Henri Gratien Bertrand w towarzystwie byłego pruskiego komendanta placu szczecińskiej twierdzy mjr. Harenberga rozpoznał zbudowane na wypadek konfliktu szwedzko-pruskiego umocnienia polowe na wyspie Wolin, w Kamieniu Pomorskim i port w Świnoujściu. Z garnizonu szczecińskiego skierowano tam niewielki oddział, wzmocniony w początkach stycznia na rozkaz marszałka Mortiera batalionem 2 pułku piechoty lekkiej (kpt. Claude Josepha Armanda). Atak przybyłego z twierdzy kołobrzeskiej oddziału kpt. Karla Wilhelma von Waldenfelsa (600 żołnierzy) przyniósł 6 stycznia 1807 roku ciężką porażkę stronie pruskiej $^{63}$.

Próbę przeciwdziałania ze strony francuskiej zorganizował również energiczny gubernator generalny Prus gen. Henri Jacques Clarke. Na rozkaz Napoleona 28 stycznia 1807 roku skierował przez Szczecin nadciągające w tym czasie do Wielkiej Armii oddziały (pułk fizylierów gwardii, dwa pułki piechoty włoskiej, 15 pułk strzelców konnych wraz z artylerią). Ich głównym zadaniem miało być dołączenie

${ }^{61}$ Nastroje takie pogłębiło wzięcie do niewoli w Choszcznie 12.01.1807I podróżującego bez eskorty gen. C. Victora. E. Höpfner, Der Krieg..., t. IV, s. 324; zob. G. Brzustowicz, Pojmanie francuskiego generała. Epizod, który wptyną na los wojen napoleońskich, „Nadwarciański Rocznik Historyczno-Archiwalny" 2008, nr 15, s. 61-64.

${ }^{62} \mathrm{Na}$ wyspie Uznam operował oddział rotmistrza Friedricha Ludwika Ungerlanda, uprawiający także partyzantkę na Zalewie Szczecińskim (Grosse Haff); D. Blecks, Ein pommerscher Volksheld in der Franzosenzeit von Otto Altenburg, Stettin 1939, s. 20-23; B. Frankiewicz: Wojny..., s. 237.

${ }^{63}$ E. Höpfner, Der Krieg..., t. IV, s. 320-321; Geschichte der Kriege in Europa sei dem Jahre 1792, Berlin, Posen, Bromberg 1834, s. 290-291. We francuskich dokumentach oficjalnych informowano o pokonaniu liczących 1000 piechoty i 100 kawalerii wojsk pruskich, wzięciu 100 jeńców i 4 dział. 52 Bulletin de la Grande Armee, Warszawa 19.01.1807, Correspondance..., t. XIV, nr 11668, s. 218. 
do sił blokujących twierdzę kołobrzeską, ale w marszu przez Pomorze Zachodnie realizowano zadanie oczyszczenia rejonu z uciążliwych oddziałów pruskich. Podjęte działania były uzasadnione, bowiem zagony pruskie docierały w tym czasie do Stepnicy, Stargardu, Choszczna, Dąbia i Gryfina ${ }^{64}$. Przeprowadzono również wyprawy za Odrę (np. 60-osobowy oddział 11.02.1807 dotarł do Pasewalku, a następnie powrócił do Nowogardu), wzbudzając niepokój wśród Francuzów. Były to akcje uciążliwe, ale bez szans na trwałe opanowanie terenu, zwłaszcza większych miast. Całkowitym niepowodzeniem zakończyła się podjęta 16 lutego 1807 roku próba zajęcia Stargardu. Prusacy niespodziewanie dla siebie napotkali na silny opór ze strony trzech kompanii 1 pułku piechoty włoskiej (gen. Antoni Bonfanti), ponosząc w walce duże straty ${ }^{65}$. Przeznaczona do blokady Kołobrzegu, włoska dywizja gen. Pierre (Pietro) Theulie przyczyniła się do uwolnienie francuskich linii komunikacyjnych od sygnalizowanych zagrożeń. Na ostateczne załamanie aktywności Freikorpsu Schilla wpłynęły ciężkie straty poniesione w walkach z wojskami włoskimi gen. Angelo Pietro Moroniego o Nowogard (17-18.02.1807) oraz zacieśniający się rejon działania w związku ze zbliżaniem się wojsk napoleońskich do Kołobrzegu ${ }^{66}$.

Zgodnie z przewidywaniami Napoleona, zagrożenie dla Szczecina i francuskich linii komunikacyjnych nadeszło ze strony Pomorza szwedzkiego. Korzystając z osłabienia sił francuskich, spowodowanego rozpoczęciem blokady Kołobrzegu, gen. Hans Henric Essen rozpoczął 1 kwietnia 1807 roku ofensywę, odrzucając blokującą Stralsund dywizję gen. Charlesa Louisa Grandjeana. Francuzi zostali zmuszeni do upokarzającego odwrotu przez Greifswald w kierunku Szczecina, podczas którego ponieśli znaczne straty w ludziach (zwłaszcza w jeńcach) i sprzęcie, także w związku z odcięciem części oddziałów stacjonujących na wyspach Uznam i Wolin. Grandjean znalazł oparcie dopiero w twierdzy szczecińskiej, do której jego osłabione i mocno zdezorganizowane wojska dotarły 7 kwietnia 1807 roku $^{67}$.

${ }^{64}$ Bawiący 11.02.1807 w domu p. Katte w prawobrzeżnej dzielnicy Zdroje (Finckenwalde) gen. Thouvenot z trudem uniknął wzięcia do niewoli przez kawalerię por. Ernsta von Diezelskyego, niepokojącą francuską załogę Dąbia; J. Haken, Ferdinand von Schill. Eine Lebensbeschreibung nach originale Papieren, Bd. I, Leipzig 1824, s. 126.

${ }^{65}$ Atakowały: oddział Schilla (400 piechoty, 250 kawalerii) i por. F. Blankenburga (160 piechoty, 20 kawalerii); E. Höpfner, Der Krieg..., t. IV, s. 337; Ch.D. Teske, Geschichte der Stadt Stargard, Stargard 1843, s. 181-182.

${ }^{66}$ E. Höpfner, Der Krieg..., s. 342-344; B. Frankiewicz: Wojny..., s. 238; H. Kroczyński: Twier$d z a \ldots$.., s. 36-37; zob. Napoleon do marszałka [Francois Josepha] Lefebvre, Osterode 19.03.1807, Napoleon do gen. Clarke, Osterode 1.04.1807, Correspondance..., t. XIV, nr 12088, s. 475; t. XV, nr 12259, s. 6.

67 Według Preussisch-russischer Kriege gegen Frankreich 1806-1807. Reluitionsrecht, Bd. 24, red. H.A. Pierer, Altenburg 1844, s. 28, straty wyniosły 1600 ludzi; zob. reakcję 
Sukces gen. Essena okazał się krótkotrwały. Poinformowany o wystąpieniu Szwedów Napoleon szybko zareagował, powierzając dowództwo marszałkowi Mortierowi. W kierunku Szczecina udała się część wojsk francuskich blokujących Kołobrzeg. Dotarły tam również oddziały przysłane przez gen. Clarke (15 pułk piechoty liniowej i pułki prowizoryczne), wzmacniając zgrupowaną w Szczecinie dywizję gen. Pierre Louisa Dupasa. Dodatkowo z Poznania skierowany został 3 pułk piechoty ${ }^{68}$. Po przybyciu do Szczecina 13 kwietnia 1807 roku i założeniu tu kwatery głównej, Mortier przeprowadził reorganizację dywizji Grandjeana. Po dwóch dniach dysponował już siłami 12 tys. żołnierzy ${ }^{69}$, rozmieszczonymi pomiędzy Szczecinem i Pasewalkiem, całkowicie wystarczającymi do przeprowadzenia kontrofensywy. Zgodnie z dyspozycją Napoleona, pierwszym jego zadaniem było zabezpieczenie Berlina, linia operacyjna przebiegać miała przez Szczecin i osłaniać oblężenie Kołobrzegu oraz linie komunikacyjne Wielkiej Armii. W walkach rozpoczętych 15/16 kwietnia 1807 roku oddziały szwedzkie zostały odrzucone w kierunku Stralsundu, a te które pozostały na wyspach Uznam i Wolin, zmuszono do kapitulacji. Podpisane 18 kwietnia 1807 roku zawieszenie broni w Schlattkow k. Anklam, ustalające linię demarkacyjną na Peene i Trebel, zakończyło aktywne działania na Pomorzu w tej fazie wojny. Mortier rozlokował swoją piechotę na kwaterach pomiędzy Szczecinem a Pasewalkiem, a kawalerię (gen. Jeana Thomasa Lorge) w Meklemburg-Strelitz, obsadził również garnizonami wyspy Uznam i Wolin. Kwatera główna VIII korpusu powróciła do Szcze$\operatorname{cina}^{70}$. W maju Mortier otrzymał kolejny rozkaz nakazujący pozostawienie jednej dywizji (gen. Louis Henri Loisona) pod Kołobrzegiem i przesunięcie drugiej (gen. Dupasa) w kierunku Gdańska.

Dla strony francuskiej zawieszenie broni oznaczało również czasowe wyeliminowanie możliwości współdziałania szwedzko-pruskiego, biorąc pod uwagę

Napoleona na niepowodzenia: „Quelle mediocrite! Cele est incroyable”. Napoleon do gen. Clarke, Finkenstein [Kamieniec Suski] 11.04.1807, Correspondance..., t. XV, nr 12343, s. 57.

$68 \mathrm{Au}$ general Thouvenot, Finkenstein 7.04.1807, w: Precis des evenements militaire, t. XIX. Campagnes de 1806 et 1807 par M. Dumas, 1826, s. 250.

${ }^{69}$ Napoleon do gen. Clarke, Finkenstein 20.04.1807, Correspondance..., t. XV, nr 12431, s. 121.

${ }^{70}$ E. Höpfner, Der Krieg..., t. IV, s. 457-458; O. Lettow-Vorbeck, Der Krieg..., t. IV, s. 216219; A. Thiers, Historya ..., t. IV, s. 156-157; zob. 72 Bulletin de la Grande Armee, Finkenstein 27.04.1807, Correspondance..., t. XV, nr 12459, s. 140-141; J. Staszewski: Wojsko polskie..., s. $156-157$. 
formowanie na wyspie Rugia ochotniczego korpusu pruskiego (gen. Gebharda Blüchera), przeniesionego następnie do rejonu Greifswald-Wolgast.

Utworzonemu w początkach maja Korpusowi Obserwacyjnemu Wielkiej Armii powierzono osłonę francuskich linii komunikacyjnych od Ems po Odrę dla przeciwstawienia się możliwemu desantowi sił prusko-angielskich. Dowództwo sprawował marszałek Gillaume Marie Anne Brune, z kwaterą główną w Szczecinie $^{71}$. W związku z zintensyfikowaniem działań oblężniczych pod Kołobrzegiem i planowanymi operacjami na Pomorzu szwedzkim z twierdzy szczecińskiej uczyniono wówczas jeden z największych arsenałów na okupowanych terenach pruskich, gromadząc tu wielkie zapasy amunicji dla artylerii i piechoty ${ }^{72}$. Podjęta już po zawarciu traktatu tylżyckiego, 13 lipca 1807 roku ofensywa zakończyła się całkowitym sukcesem wojsk francuskich i sojuszniczych, zajęciem Stralsundu (20.08.1807) oraz Rugii $(9.09 .1807)^{73}$, a w konsekwencji, likwidacją panowania szwedzkiego na Pomorzu.

Postawione przez Napoleona zadania zostały, przez zmieniający się pod względem liczebności i składu garnizon Szczecina, wypełnione. Pomimo słabości sił tu zgromadzonych, stosując system rotacji wojsk, dowództwo francuskie zorganizowało strategiczne zadanie obrony linii Odry w jej dolnym biegu ${ }^{74}$. Kluczowej wagi nabierały kwestie logistyczne. Zgrupowania wojsk francuskich i sojuszniczych, kierowane nad Wisłę, mogły się zaopatrywać w szczecińskiej twierdzy. Wreszcie spełniła ona rolę podstawy operacyjnej dla działań bojowych prowadzonych na obu stronach Odry.

${ }^{71}$ Skład i zadania korpusu zob. Instructions pour le Marechal Brune, Finkenstein 29.04.1807, Correspondance..., t. XV, nr 12494, s. 170-171; E. Höpfner, Der Krieg..., t. IV, s. 460-461; A. Thiers, Historya ..., t. IV, s. 193.

${ }^{72} \mathrm{Na}$ pocz. maja $1807 \mathrm{r}$. znajdowało się tutaj 285 dział, obsługiwanych przez kompanię francuskiej artylerii; w magazynach twierdzy zgromadzono 82976 kul, 10320 ładunków artyleryjskich, 177660 kg prochu i 1099200 sztuk amunicji piechoty. G. Lechartier, Les Services..., s. 439-440.

73 Zob. J. de Vigier, Precis historique de la Campagne faite en 1807 dans la Pommeranie Suedoise, Limoges 1825, s. 25-90; E. Höpfner, Der Krieg..., t. IV, s. 466-469.

${ }^{74} \mathrm{Na}$ podstawie układu francusko-pruskiego z 8.09.1808 r. Francuzi uzyskali prawo utrzymywania swoich garnizonów w Szczecinie, Kostrzynie i Głogowie. Według stanu z 31.05.1809 w Szczecinie pod komenda gen. J. Lieberta stacjonowały wojska francuskie (batalion 22 pułku piechoty - 411, kompania artylerii - 76), saskie (batalion pułku piechoty Diherrna - 375) i polskie (III batalion 10 pułku piechoty - 491 oraz 4 pułk strzelców konnych - 236); J.H. Gill, 1809 Thunder on the Danube. Napoleon's Defeat of the Habsburgs, vol. III, 2008, s. 377. Zmiany w liczebności garnizonu zob. B. Frankiewicz: Garnizony..., s. 10-11. 


\section{Bibliografia}

\section{Źródła}

Allgemeines Europäischen Staats und Adress-Handbuch für dem Jahr 1809 von G. Hassel, Weimar 1809.

Correspondance de Napoleon I-er. Publiee par ordre de l'Empereur Napoleon III, t. XIII, XIV, XV, Paris 1863-1864.

Die Feldzüge von 1806 und 1807 in einer historisch, politisch, militärische Darstellung nebst den offiziellen Aktenstücken, Zweiter Teil, b.m.w., 1809.

Foucart P.J., Campagne de Prusse (1806) a'pres les archives de la guerre, Paris 1890.

Foucart P.J., Campagne de Pologne novembre-decembre 1806-janvier 1807 (Pultusk et Golymin) a'apres les archives de la guerre, t. I-II, Paris 1882.

Foucart P.J., La cavalerie pendant la campagne de Prusse (7 octobre-7 novembre 1806), Paris 1880.

Haken J., Ferdinand von Schill. Eine Lebensbeschreibung nach originale Papieren, Bd. I, Leipzig 1824.

Handbuch über den Königlich-Preussischen Hof und Staat für das Jahr 1804, [b.m.w.], s. 461.

Preussisch-russischer Kriege gegen Frankreich 1806-1807. Reluitionsrecht Bd. 24, red. H.A. Pierer, Altenburg 1844.

Schleiermacher F., Briefwechsel und biographische Dokumente. B. 9, Briefwechsel 1806-1807, Berlin 2011.

Seebach L.v., Geschichte des Feldzüges des herzoglich Sachsen-Weimarischen Scharffschützenbattalions im Jahr 1806 und des Infanterieregiments der Herzoge von Sachsen in den J. 1807, 1808, 1810 und 1811, Weimar 1838.

Teske Ch.D., Geschichte der Stadt Stargard, Stargard 1843.

Thiede F., Chronik der Stadt Stettin, Stettin 1849.

Thiers A., Historya Konsulatu i Cesarstwa, t. III, Warszawa 1847; t. IV, Warszawa 1850.

Victoires, conquetes et desastres, Revers et Guerres Civiles des Francais de 1792 a 1815, t. 7, Paris 1819.

Vigier J. de, Precis historique de la Campagne faite en 1807 dans la Pommeranie Suedoise, Limoges 1825.

\section{Opracowania}

Bielecki R., Wielka Armia Napoleona, Warszawa 1995.

Binder von Krieglstein Ch., Ferdinand von Schill, Berlin 1902.

Blasendorf [Karl], Aus der Franzosenzeit, „Baltische Studien” 1879, nr 29 .

Blecks D., Ein pommerscher Volksheld in der Franzosenzeit von Otto Altenburg, Stettin 1939.

Bock H., Major Schill, der Treubrecher. Zwischen Patriotismus und Staatsräson, Berlin 2013.

Branig H., Die Polen im Pommern im Frühjahr 1807, „Baltische Studien” 1935, nr 37. 
Brzustowicz G., Pojmanie francuskiego generała. Epizod, który wpłynąt na los wojen napoleońskich, „Nadwarciański Rocznik Historyczno-Archiwalny” 2008, nr 15.

Chojnacki M., Z dziejów polskiej Legii Północnej 1806-1808, „Wojskowy Przegląd Historyczny" 1960, nr 1.

Domalski C., Napoleoński Szczecin 1806-1813, Szczecin 2009.

Dupont M., Generat Lassalle, tłum. B. Wieniawa-Długoszowski, Kraków 1983.

Dzieje Szczecina 1806-1945, red. B. Wachowiak, t. III, Szczecin 1994.

Encyklopedia wojen napoleońskich, Warszawa 2001.

Frankiewicz B., Wojny napoleońskie na terenie Pomorza Zachodniego, w: Z dziejów wojennych Pomorza Zachodniego. Cedynia 972 - Siekierki 1945, red. B. Miśkiewicz, Poznań 1972.

Frankiewicz B., Garnizony wojsk francusko-polskich na Pomorzu Szczecińskim i Gdańskim w latach 1807-1813, „Przegląd Zachodniopomorski” 1969, nr 2.

Fritz E., Aus schwerer Zeit. Erinnerungen an die Drangsale und Leiden der Stadt und Festung Altdamm aus der Zeit der Franzosenherrschaft in den Jahren 1806-1813, Altdamm 1902.

Für die Freiheit, gegen Napoleon. Ferdinand von Schill, Preussen und die Deutsche Nation, Köln, Weimar, Wien, Böhlau 2009.

Für die Freiheit, gegen Napoleon. Ferdinand von Schill, Preussen und die Deutsche Nation, Köln, Weimar, Wien, Böhlau 2009.

Gembarzewski B., Wojsko Polskie. Księstwo Warszawskie 1807-1814, Warszawa 1905.

Geschichte der Kriege in Europa sei dem Jahre 1792, Berlin, Posen, Bromberg 1834.

Gill J. H., 1809 Thunder on the Danube. Napoleon's Defeat of the Habsburgs, vol. III, 2008

Gottberg G., Ein unbelohnter Held, „Pommersche Tagespost”, 21.08.1927.

Granier H., Die Kapitulation von Stettin 1806 und der Staatsminister von Ingersleben, „Baltische Studien” 1900, nr 4.

Handwerg M., Die Belagerung der Festung Stralsund 1807 und deren Folgen für Vorpommern. Tagebuchaufzeichnungen eines Vertrauten, b.m.w. 2009.

Höpfner E., Der Krieg von 1806 und 1807. Ein Beitrag zur Geschichte der Preussischen Armee nach den Quellen des Kriegs-Archivs bearbeitet, Berlin 1852, wyd. polskie: Wojna z lat 1806-1807, t. I-IV, Oświęcim 2014-2016.

Kemm H., Die Garnisonorte der preussische Armee in Pommern von 1740-1806, Berlin 1937 (1983).

Kircheisen F., Napoleon I. Obraz życia, t. II 1806-1821, Oświęcim 2015.

Kroczyński H., Twierdza Kołobrzeg, Warszawa 1998.

Kroczyński H., Wojsko polskie na Pomorzu Zachodnim i Krajnie w 1807, Warszawa 1990.

Kukiel M., Dzieje oręża polskiego w dobie napoleońskiej 1795-1815, Poznań 1912.

Kukiel M., Wojny napoleońskie, Warszawa 1927. 
Lechartier G., Les Services de l'arriere a la Grande Armee en 1806-1807, Paris 1910.

Lechartier G., Manewr na Pultusk, Oświęcim 2011.

Lettow-Vorbeck O. von, Der Krieg von 1806 und 1807, t. II, IV, Berlin 1892, 1896.

Mikuła W.S., Działania zbrojne na Pomorzu w okresie wojen napoleońskich, w: Działania militarne na Pomorzu, red. W. Wróblewski, Warszawa 2001.

Nadzieja J., Gen. Józef Zajączek 1752-1826, Warszawa 1975.

Pachoński J., Legiony Polskie. Prawda i legenda 1794-1807, t. IV, „Z ziemi włoskiej do Polski” 1800-1807, Warszawa 1979.

Petre F.L., Napoleon's Conquest of Prussia, London 1914.

Staszewski J., Wojsko polskie na Pomorzu w roku 1807, wyd. II, Oświęcim 2013.

Staszewski J., Źródła wojskowe do dziejów Pomorza w czasach Księstwa Warszawskiego, cz. I., Zajęcie Pomorza 1806/7, Toruń 1933.

Stelmach M., Pruskie władze administracyjne miasta Szczecina w okresie okupacji francuskiej (1807-1813), „Przegląd Zachodniopomorski” 1980, nr 1.

Szultka Z., Pomorze Zachodnie w czasie wojen napoleońskich, w: Historia Pomorza, red. G. Labuda, t. II, cz. III, Poznań 2003.

Thoumas Ch.A., Le Marechal Lannes par le gen..., Paris 1891.

Tulard J., Murat, Gdańsk 2002.

Turek-Kwiatkowska L., Społeczeństwo pomorskie wobec rewolucji francuskiej $i$ wojen napoleońskich, „Szczecińskie Studia Historyczne” 1991, nr 4.

Wehrmann M., Geschichte der Stadt Stettin, Stettin 1911.

Wojsko polskie na Pomorzu Zachodnim i Krajnie w 1807, Warszawa 1990.

Zimmermann O., Ferdinand von Schill. Ein Heldenleben, Berlin 1948.

Zych G., Rok 1807, Warszawa 1957.

\section{Abstrakt}

W napoleońskim systemie prowadzenia wojny twierdze odgrywały ważną rolę jako „oparcie dla manewru”, zabezpieczenie linii komunikacyjnych armii, stawały się „ośrodkami operacji”, podstawą gromadzenia rezerw i zaopatrzenia wojsk (magazyny i sprzęt). W artykule przedstawiono rolę twierdzy szczecińskiej w koncepcjach Napoleona i ich realizacji w okresie od końca października 1806 do sierpnia 1807 roku, zamykającego bezpośrednie działania wojenne wokół Szczecina (i na Pomorzu szwedzkim). Fakt, że na interesującym nas obszarze nie doszło do spektakularnych walk i oblężeń, jak w przypadku Gdańska, Kołobrzegu, Grudziądza, a także twierdz śląskich, wpłynął na mniejsze zainteresowanie badaczy działaniami wojennymi na Pomorzu Zachodnim. 


\title{
The Strategic Role of the Szczecin Stronghold DURING THE 1806-1807 WAR
}

\begin{abstract}
In the Napoleonic system of fighting wars strongholds played an important role as a backup for manoeuvre and securing communications routes for the army; in addition, strongholds became operational centres, where reserve and supplies were kept. The paper presents the role of the Szczecin Stronghold in the concepts of Napoleon and how they were implemented form October 1806 to August 1807 closing the direct military activities around Szczecin (and in the Swedish Pomerania). It is because of the fact that in the area in question there were no spectacular battles or sieges, as in the case of Gdańsk, Kołobrzeg, Grudziądz, as well as in the case of Silesian strongholds, that the interest in the war that took place there at the beginning of the 19th century has never been so great.
\end{abstract}

